\title{
Realizacja polityk publicznych przez administrację publiczną
}

\section{Wprowadzenie}

Realizacja zadań publicznych przez państwo i jego struktury jest przedmioRtem analizy wielu dyscyplin badawczych. Złożoność problemów badawczych wymaga precyzyjnego ich ujęcia oraz wskazania zakresów, w których interdyscyplinarne ujęcie pozwoli na możliwie najpełniejsze odzwierciedlenie badanych zjawisk.

W ramach systematyki dyscyplin naukowych, które zajmują się w szerokim ujęciu realizacją działań państwa wyróżnić należy: nauki prawne, nauki o administracji, zarządzanie publiczne, nauki o polityce oraz kształtujące się obecnie nauki o polityce publicznej. W tym kontekście A. Zybała trafnie wskazuje, że: „nauki prawne prezentują ramy normatywne, w których funkcjonuje system państwowy, nauki o zarządzaniu publicznym formułują tezy o sposobach funkcjonowania państwa, jako systemu form organizacyjnych, nauki polityczne zaś opisują państwo od strony mechanizmu rywalizacji grup politycznych (...). Natomiast nauka o politykach państwa opisuje treść funkcjonowania państwa (...). Dotyczy ona, zatem sposobu, w jakim państwo radzi sobie z kluczowymi problemami i wyzwaniami, które dotykają tworzące je społeczeństwa". ${ }^{1}$

Wzrost zainteresowania osiąganiem celów publicznych jest uwarunkowane rosnącym znaczeniem ingerencji podmiotów publicznych w poszczególne sfery życia społecznego. Jest to jednak ingerencja odbywająca się w warunkach zasad demokratycznego państwa prawnego, w których władcze działanie organu państwowego winna mieścić się w granicach gwarantowanych praw i wolności. Z tego

\footnotetext{
* Dr нав. Jan Izdebski - Katolicki Uniwersytet Lubelski Jana Pawła II, Wydział Prawa, Prawa Kanonicznego i Administracji, Katedra Zarządzania Publicznego i Prawa Administracyjnego

${ }^{1}$ A. Zybała, Polityki publiczne, Krajowa Szkoła Administracji Publicznej, Warszawa 2012, s. 8.
} 
względu przy określaniu celów i zasad aktywności państwa w poszczególnych jego sferach działania powinno uwzględniać się perspektywę prawnych granic jego ingerencji uregulowanych normami prawa administracyjnego.

Celem niniejszego opracowania jest wskazanie zależności pomiędzy pojęciem i stosowaniem polityk publicznych a działaniami administracji publicznej związanymi z ich realizacją.

\section{Pojecie polityk publicznych a system nauk administracyjnych}

Polityki publiczne - jak podkreśla A. Zybała - „można określić, jako dziedzinę systemowych, uporządkowanych działań państwa i jego obywateli, które (...) wypływają z wytworzonej zobiektywizowanej wiedzy i są podejmowane, aby rozwiązywać kluczowe problemy społeczne. ${ }^{2} \mathrm{~W}$ tym kontekście interpretacyjnym pojęcie polityki publicznej związane jest $\mathrm{z}$ działaniami państwa i podmiotów, które uczestniczą w rozwiązywaniu problemów społecznych. D. Kozaczka wskazuje natomiast, że polityka publiczna oznacza: „wiedzę o rozwiązywaniu problemów społecznych. A w praktyce proces działań systemowych, realizowanych przez instytucje władzy publicznej (m.in. administrację rządową i samorządową) w celu rozwiązywania problemów w różnych obszarach życia społecznego oraz tworzenie optymalnych warunków rozwoju lokalnego i regionalnego"3. J. Woźnicki podkreśla natomiast, że: „polityka publiczna postrzegana jest, jako podejmowanie przez władzę publiczną powiązanych ze sobą decyzji i działań dla osiągnięcia określonych celów, w sytuacji, gdy mechanizmy rynkowe nie mają zastosowania albo same nie mogłyby działać dostatecznie efektywnie. Polityka publiczna jest inicjowana przez władzę publiczną w imieniu społeczeństwa/społeczności lokalnej, jest określana, interpretowana i realizowana przede wszystkim przez podmioty publiczne, rzadziej przez prywatne i pozarządowe (...)."4

Poszczególne polityki publiczne jak podkreśla A Zybała, wykonywane są za pomocą szeregu specyficznych narzędzi, takich jak regulacje (prawne, ale także samoregulacje różnych grup obywateli czy biznesu), współpraca, argumentowanie, debatowanie, badanie, kształtowanie pozytywnych bodźców do przyjmowania oczekiwanych postaw, wskaźniki efektywności działań, ewaluacja, ekspertyzy, instytucje (urzędy publiczne oraz sieci współpracy organizacji społecznych). ${ }^{5}$ Przedstawione narzędzia realizacji polityk publicznych obok

2 Tamże, s. 13.

3 D. Kozaczka, Polityki publiczne, jako proces, Zoon Politikon, Nr 7 2016, s. 327.

4 J. Woźnicki, Nowa dyscyplina - „nauki o polityce publicznej” usytuowana w dziedzinie nauk społecznych, Nauka Nr 1/2012, s. 133.

5 A. Zybała, ... dz. cyt., s. 13. 
istotnych form współpracy z podmiotami prywatnymi i społecznymi wskazują na istotną rolę struktur administracji publicznej.

$\mathrm{W}$ ramach systemu nauk administracyjnych, mających za przedmiot w szerokim ujęciu badania nad administracją publiczną, wyróżnia my naukę administracji, naukę prawa administracyjnego, (która, jako nauka prawna jest częścią dogmatyki prawa) oraz politykę administracyjną. W tym miejscu zasadne jest wskazanie zależności pomiędzy polityką publiczną a tym tradycyjnym elementem systemu nauk administracyjnych, - jakim jest polityka administracyjna. Według J. Starościaka nauka polityki administracyjnej jest nauką o wykorzystywaniu możliwości w ramach prawa ${ }^{6}$. Zdaniem J. Szreniawskiego przedmiotem polityki administracyjnej jest analiza, przewidywanie skutków działania i wykorzystywanie możliwości działania w ramach prawa, przygotowywanie programów działania administracji oraz weryfikacja ich realizacji, a także wysuwanie postulatów dotyczących zmian w całokształcie funkcjonowania administracji. Ponadto ważnym elementem polityki administracyjnej jest ocena, na ile przepisy prawa administracyjnego przyczyniają się do realizacji polityki państwa i czy polityka państwa jest podstawą do interpretacji norm prawnych $^{7}$. T. Kuta natomiast określił politykę administracyjną, jako wiedzę praktyczną, która wypracowuje zasady zapobiegania przez administrację konfliktom w życiu społecznym i gospodarczym ${ }^{8}$. M. Jełowicki definiując politykę administracyjną podkreślał, że jest ona jednym z elementów polityki państwa i należy przez nią rozumieć ustalane - na podstawie politycznych programów rozwoju państwa i społeczeństwa - programy, założenia i kierunki działania administracji, obejmujące w szczególności jej cele, a także systemy preferencji i systemy wartościowania służące realizacji tych celów ${ }^{9} \mathrm{Z}$ kolei według Z. Leońskiego polityka administracyjna to dziedzina wiedzy badająca cele i programy administracji, zajmująca się oceną i weryfikacją tychże celów i programów ustalonych dla poszczególnych działów administracji publicznej oraz wskazująca rozwiązania w zakresie stosowanych metod i instrumentów koniecznych do osiągnięcia wyznaczonych celów. ${ }^{10}$ Obecnie zagadnienia polityki administracyjnej są najczęściej omawiane w ramach opracowań z zakresu nauki administracji. Zdaniem E. Knosali wyodrębnienie polityki administracyjnej, jako odrębnej nauki jest dyskusyjne, natomiast zagadnienia dotyczące celowego kształtowania działań administracji powinny być integralną częścią nauki administracji. $\mathrm{W}$ proponowanym ujęciu nauka administracji powinna mieć charakter zarówno

${ }^{6}$ J. Starościak, Prawo administracyjne, Warszawa 1977, s. 26.

7 J. Szreniawski, Wstęp do nauki administracji, Lublin 2000, s. 10.

${ }^{8}$ J. Boć, T. Kuta, Prawo administracyjne. Zagadnienia podstawowe, Warszawa 1984, s. 32.

${ }^{9}$ M. Jełowicki, Nauka administracji. Zagadnienia wybrane, Warszawa 1987, s. 318 i n.

${ }_{10}$ Z. Leoński we współpracy z R. Hauserem i A. Skoczylasem, Zarys prawa administracyjnego, Warszawa 2004, s. 25. 
deskryptywny (opisowy) jak i preskryptywny (normatywny) ${ }^{11}$. Tak wskazany zakres polityki administracyjnej z jednej strony mieści się w spektrum merytorycznym polityk publicznych, $\mathrm{z}$ drugiej strony polityka publiczna jest pojęciem zdecydowanie szerszym i obejmującym więcej elementów niż wyspecjalizowana pod kątem działań administracji publicznej polityka administracyjna.

Rozumienie polityki publicznej wynika z jej rodowodu, związków z kulturą i nauką anglosaską i przesądza o bezpośrednich relacjach z pojęciami wykształconymi w ramach zarządzania publicznego. Natomiast zagadnienie pojęcia i zakresu polityki administracyjnej powinno być rozpatrywane w nawiązaniu do kontynentalnej ścieżki rozwoju nauk o administrowaniu - nauki prawa administracyjnego i nauki administracji. Zgodzić się należy z M. Kuleszą i D. Sześciło, że są to pojęcia w znaczącym stopniu rozbieżne. ${ }^{12}$ Pamiętać jednak należy, że tworzenie i realizacja poszczególnych polityk publicznych jest związana z udziałem podmiotów administracji publicznej - w takich sytuacjach konkretne polityki publiczne mogą być traktowane, jako części polityki administracyjnej (można w tym miejscu wskazać politykę gospodarczą, politykę społeczną, politykę fiskalną, politykę oświatową, politykę ekologiczną, politykę energetyczną, politykę celną oraz wiele innych działów polityki administracyjnej). ${ }^{13}$ Zależność to powinna być szczególnie dostrzegana w kontekście kontynentalnego modelu administracji publicznej, w którym rola prawa administracyjnego i stosującej jego normy administracji publicznej jest istotna, $\mathrm{w}$ stosunku do pozostałych aktorów życia publicznego zaangażowanych w tworzenie polityk publicznych. Zgodzić się w tym zakresie należy z A. Makuch, że: „status, cele i zakres obowiązków administracji publicznej każdego szczebla zależą w perspektywie szerszej niż bieżąca legislatywa od narodowej kultury prawno-politycznej kształtowanej przez oddziaływanie dominujących doktryn filozoficznych, ustrojowych, prawnych i politycznych" ${ }^{14}$. Z tego względu należy uznać, że administracja publiczna jest obecnie podstawowym systemem podmiotów uczestniczących w tworzeniu i realizacji polityk publicznych. Rozwój koncepcji polityki publicznej ze swoim rodowodem ma natomiast na celu wzrost udziału podmiotów spoza struktury administracji publicznej w rozwiązywaniu problemów społecznych i tym samym zwiększenie partycypacji społecznej.

${ }^{11}$ E. Knosala, Zarys nauki administracji, Kraków 2005, s. 24.

${ }_{12}$ M. Kulesza, D. Sześciło, Polityka administracyjna i zarzq̨dzanie publiczne, Warszawa 2013, s. 19.

13 Z. Leoński, Nauka administracji, Warszawa 2004, s. 17., J. Izdebski, Pojęcie i zakres polityki celnej w ujęciu polityki administracyjnej, [w:] J. Łukasiewicz (red.), Polityka administracyjna, IV Międzynarodowa Konferencja Naukowa Stryków 7-9 września 2008 r., Rzeszów 2008, s. 267 in.

${ }_{14}$ A. Makuch, Rola administracji publicznej w świetle wybranych nurtów i doktryn politycznych [w:] A. Gołębiowska, B. Zientarski (red.) Koncepcje i instrumenty zarządzania $w$ administracji publicznej, Kancelaria Senatu, Warszawa 2017, s. 73. 


\section{Rola administracji publicznej i materialnego prawa administracyjnego we wdrażaniu polityk publicznych}

Przedstawione dotychczas zagadnienia uprawniają do stwierdzenia, że administracja publiczna dla podmiotów tworzących polityki publiczne jest narzędziem, instrumentem ich wdrażania oraz następnie oceny ich stosowania. Taki sposób rozumienia roli administracji publicznej mieści się e sposobie jej definiowania w doktrynie prawa administracyjnego. W ujęciu H. Izdebskiego i M. Kuleszy przez administrację publiczną rozumie się zespół działań, czynności i przedsięwzięć organizatorskich i wykonawczych, prowadzonych na rzecz realizacji interesu publicznego przez różne podmioty, organy i instytucje, na podstawie ustawy i określonych w prawie formach. ${ }^{15} \mathrm{Na}$ podstawie tej definicji Z. Niewiadomski wskazuje, że administracja publiczna to ogół działań o charakterze organizatorskim i wykonawczym, mających na celu realizację dobra wspólnego przez różne podmioty (niekoniecznie państwowe) związane, co do podstawy i form działalności ustawą, pozostając pod kontrolą społeczną ${ }^{16}$ Traktowanie administracji publicznej, jako systemu podmiotów realizujących określoną politykę publiczną jest spojrzeniem na działanie administracji publicznej z punktu widzenia nauk o polityce publicznej.

Realizacja poszczególnych polityk publicznych będących w sferze administracji publicznej w swojej istocie dotyczy wyspecjalizowanych zakresów działania administracji publicznej. Z tego względu z punktu widzenia systematyki prawa administracyjnego poszczególne polityki publiczne powinny być interpretowane w powiązaniu $\mathrm{z}$ konkretnymi wyspecjalizowanymi działami materialnego prawa administracyjnego. Materialne prawo administracyjne jest fundamentem, na którym budowany jest cały system prawa administracyjnego. Normy prawa materialnego określają prawa i obowiązki obywateli oraz innych podmiotów, wynikające $\mathrm{z}$ funkcjonowania w państwie i zbiorowości, zobowiązując jednocześnie organy administracji publicznej do zachowań prawem nakazanych. ${ }^{17}$ Jak słusznie podkreśla J. Jagielski treści norm prawa administracyjnego są pod względem merytorycznym determinowane różnymi czynnikami, wśród których rolę pierwszoplanową odgrywają czynniki aksjologiczne. ${ }^{18}$ Regulacje

${ }^{15}$ H. Izdebski, M. Kulesza, Administracja publiczna. Zagadnienia ogólne, Warszawa 2000 , s. 79.

16 Z. Niewiadomski, Pojęcie administracji publicznej, [w:] R. Hauser, Z. Niewiadomski, A. Wróbel (red .), System prawa administracyjnego, t . 1: Instytucje prawa administracyjnego, Warszawa 2010 .s. 58.

17 Z. Niewiadomski, Istota i miejsce prawa materialnego $w$ systemie prawa administracyjnego, [w:] Z. Niewiadomski (red.), Prawo administracyjne. Część materialna, Warszawa 2004, s. 18.

${ }_{18} \mathrm{~J}$. Jagielski, Rozważania nad pojęciem i istota prawa administracyjnego materialnego, [w:] R. Hauser, Z. Niewiadomski, A. Wróbel (red.), System prawa administracyjnego. Tom 7. Prawa administracyjne materialne, Warszawa 2012, s. 30. 
materialnego prawa administracyjnego odzwierciedlają, zatem szczegółowe cele i wartości, które chce osiągnąć ustawodawca ustanawiając w określonych sferach metody regulacji prawa administracyjnego.

Administracja publiczna rozumiana, jako system podmiotów realizujących zadania publiczne ukierunkowane na osiąganie dobra wspólnego w poszczególnych sferach ingerencji działa na podstawie przepisów materialnego prawa administracyjnego. Konstrukcja norm prawa administracyjnego musi być ukierunkowana na ochronę praw jednostki przy stosowaniu niezbędnej ingerencji w życie jednostek i zbiorowości - ingerencji niezbędnej ze względu na ochronę interesu publicznego i w konsekwencji realizacji dobra wspólnego.

Szeroki zakres ingerencji administracji publicznej, wszechstronny charakter i rola regulacji prawno-administracyjnych powoduje konieczność podziału zagadnień materialnego prawa administracyjnego. Jest to podyktowane względami naukowymi, dydaktycznymi jak również praktycznymi ${ }^{19}$. W ujęciu Z. Leońskiego podział materialnego prawa administracyjnego, należy przeprowadzać według sfery ingerencji administracji w określone dobra (wolności, prawa, swobody) jednostki. W tej kwalifikacji wyróżniamy następujące działy materialnego prawa administracyjnego:

1. Wolności obywatelskie i prawa człowieka,

2. Status prawny jednostki,

3. Zawody zaufania publicznego,

4. Funkcje policyjne,

5. Reglamentacja działalności gospodarczej,

6. Ingerencja administracyjna w sferę własności nieruchomości,

7. Rzeczy publiczne,

8. Strefy specjalne,

9. Ciężary publiczne,

10. Administracja świadcząca - pomoc społeczna i zabezpieczenie społeczne. ${ }^{20}$

Jak wskazuje Z. Duniewska prawo administracyjne materialne powinno być skuteczne, a w konsekwencji powinno ono sprzyjać dobrej praktyce administrowania publicznego, wzmocnionej kooperacją z podmiotami społecznymi. Autorka zwraca uwagę $w$ tym miejscu na zagadnienia wypracowane w ramach nauk o administracji i jej działaniu (w tym na naukę administracji). ${ }^{21}$

Z punktu widzenia kompetencji organów administracji publicznej realizacja poszczególnych polityk publicznych odbywa się, jako realizacja zadań związanych

${ }_{19}$ J. Izdebski, Koncepcja misji administracji publicznej w nauce prawa administracyjnego, Lublin 2012, s. 131.

${ }^{20}$ Z. Leoński, Materialne prawo administracyjne, Warszawa 2009, s. 16 in.

${ }^{21}$ Z. Duniewska, Zakres regulacji prawa administracyjnego materialnego - wyznaczenie pojęcia instytucji tego prawa, [w:] R. Hauser, Z. Niewiadomski, A. Wróbel (red.), System prawa administracyjnego. Tom 7. Prawo administracyjne materialne, Warszawa 2012, s. 121-122. 
z konkretnym działem materialnego prawa administracyjnego. W ustroju administracji publicznej opartym na zasadzie praworządności działanie podmiotów administracji publicznej jest oparte o normy prawa administracyjnego. Założenia poszczególnych polityk publicznych powinny przewidywać właściwe umocowanie do realizacji konkretnych zadań wynikających z danej polityki publicznej.

Rola administracji publicznej uwidacznia się w działaniach polegających na stosowaniu uregulowanych normami prawa administracyjnego aktów i czynności w stosunku do interesariuszy, którzy to interesariusze są adresatami szczegółowych rozwiązań, programów określonych w danej polityce publicznej. Aktualne tendencje w tym zakresie są związane z odchodzeniem od rozwiązań władczych, w których organy administracji publicznej jednostronnie kształtują prawa i obowiązki administrowanych na rzecz form niewładczych i partycypacyjnych, mających na celu zwiększeniu udziału interesariuszy w kształtowaniu i realizacji zadań publicznych oraz rozwiązywaniu problemów społecznych. Zależności te wpływają na konieczność zmian w systemie prawnych form działania administracji publicznej wykorzystywanych przy realizacji poszczególnych polityk publicznych.

\section{Prawne formy działania administracji publicznej}

Realizacja zadań administracji publicznej odbywa się przy wykorzystaniu odpowiednich, przewidzianych prawem form działania. Zagadnienia dotyczące klasyfikacji tychże form, zmian dotyczących ich stosowania należą do kluczowych problemów piśmiennictwa $\mathrm{z}$ zakresu prawa administracyjnego. $\mathrm{Z}$ racji na typowe dla regulacji prawno-administracyjnych podleganie nieustannym zmianom problematyka prawnych form działania administracji publicznej warunkuje istotne problemy badawcze i interpretacyjne. Natomiast dyskusja nad katalogiem prawnych form działania jest $\mathrm{w}$ istocie wskazaniem aktualnego stanu badań w doktrynie prawa administracyjnego. ${ }^{22}$

Przez prawną formę działania administracji rozumie się typ konkretnej czynności administracji, inaczej sposób realizacji postawionych przed nią zadań. Można też ją określić, jako wyodrębniony bądź dający się wyodrębnić, prawem określony, o utrwalonych cechach typ czynności konwencjonalnej bądź faktycznej, bądź zespół takich czynności określonego, powoływanego do wykonywania zadań z zakresu administracji publicznej podmiotu (bądź zespołu podmiotów) $\mathrm{w}$ celu wypełnienia zadań z zakresu administracji publicznej. ${ }^{23}$

${ }^{22}$ I. Lipowicz, Prawne formy działania administracji publicznej - między stabilizacja a potrzeba przełomu, Ruch Prawniczy, Ekonomiczny i Socjologiczny, Rok LXXVIII - zeszyt 4 - 2016, s. 41.

${ }^{23}$ K. M. Ziemski, Indywidualny akt administracyjny jako forma prawna działania administracji, Poznań 2005, s. 138. 
Klasyczny podział prawnych form działania administracji publicznej J. Starościaka ${ }^{24}$ jest podstawą do dostosowywania do zmieniających się prawnych podstaw działania administracji. W ramach aktualnych badań nauki prawa administracyjnego pod pojęciem prawnych form działania administracji należy rozumieć:

1. Akty stanowienia prawa (akty normatywne).

2. Akty stosowania prawa.

3. Akty administracyjne.

4. Polecenia służbowe.

5. Umowy.

6. Ugody.

7. Porozumienia.

8. Przyrzeczenie publiczne.

9. Plany, programy i strategie działania.

10. Czynności materialno-techniczne.

11. Działalność społeczno-organizatorską. ${ }^{25}$

Spośród przedstawionych form działania zwrócić należy uwagę, na formy niewładcze, które zapewniają udział administrowanych w realizacji zadań publicznych. Demokratyzacja procesów administrowania, będąca kluczowym elementem konstrukcyjnym polityk publicznych może być zapewniona przez rozwój niewładczych form działania administracji publicznej. W związku z tymi zależnościami, zwrócić uwagę należy, że do ważnych tendencji, w oparciu, o które kształtowane są postulaty wobec form i standardów działania administracji publicznej jest szerszy udział jednostek, (obywateli, przedsiębiorców (w zależności od sfery działania administracji publicznej)) tj. administrowanych w procesach administrowania (rozumianych, jako stosowanie prawa administracyjnego). Postulaty te są związane z szerszą perspektywą zwiększenia udziału czynnika społecznego, obywatelskiego w zarządzaniu sprawami publicznymi oraz zwiększeniu wpływu samych zainteresowanych (tzw. interesariuszy) poszczególnymi przypadkami władczych działań podmiotów administracji publicznej podejmowanych w oparciu o normy prawa administracyjnego.

Ukształtowany w doktrynie prawa administracyjnego sposób ujmowania prawnych form działania administracji publicznej jest w konsekwencji konfrontowany z jednej strony ze złożonym zakresem zadań administracji publicznej ponadto jest podstawą do dyskusji nad wyposażeniem podmiotów administrujących w nowe, zmodyfikowane formy działania. Realizacja zadań administracji publicznej w demokratycznym państwie prawnym jest podpo-

${ }^{24}$ J. Starościak, ...dz. cyt., s. 231.

${ }_{25}$ M. Małecka-Łyszczek, Wplyw wybranych prawnych form działania administracji na natężenie współpracy z podmiotami ekonomii społecznej, Ekonomia Społeczna, Nr 3 (8) 2013, s. 105. 
rządkowana zasadzie praworządności, stąd podmioty administracyjne powinny być wyposażone w odpowiednie instrumenty prawne służące realizacji zadania i mieszczące się w porządku prawnym. Rozwój koncepcji realizacji poszczególnych polityk publicznych wymaga prawidłowego odzwierciedlenia w katalogu prawnych form działania administracji publicznej.

Konieczność zmian w metodach działania administracji publicznej powinna wynikać $\mathrm{z}$ badań nad rzeczywistą administracją publiczną i realizowanych przez nią procesach administrowania podejmowanych $w$ ramach nauk administracyjnych. Następnie wyniki badań winny być podstawą ocen i tworzenia założeń zmian i programów działania w związku z zagadnieniami polityki administracyjnej oraz w szerszej perspektywie polityk publicznych. Następnie postulaty zmian muszą być skonfrontowane $\mathrm{z}$ instytucjami prawa administracyjnego i charakterem metod regulacji stosunków administracyjnoprawnych. Dopiero wtedy, gdy można je określić w języku norm prawnych mogą być podstawą do wprowadzenia zmian w formach działania administracji publicznej, które przesądzają o prawnej możliwości kształtowania stosunków administracyjnoprawnych pomiędzy podmiotami administrującymi i administrowanymi. ${ }^{26} \mathrm{~W}$ ramach systemu nauk administracyjnych powinny być podejmowanie badania służące rozwojowi regulacji prawa administracyjnego zgodne z zapotrzebowaniem na rozwiązywanie problemów społecznych oraz zachowującymi wysokie standardy ochrony praw podmiotów administrowanych.

\section{Podsumowanie}

Współczesne państwo w sferze publicznej podejmuje się realizacji wielu szczegółowych zestawów działań - powstających, jako odpowiedź na istotne problemy społeczne, a w swoim założeniu mający na celu ich rozwiązanie lub zahamowanie niekorzystnych procesów i zjawisk. Tworzenie ich założeń odbywa się przy wykorzystaniu metod i technik odzwierciedlających aktualny stan wiedzy oraz mechanizmów mających na celu zwiększyć partycypację społeczną przy ich powstawaniu. Tak tworzone polityki publiczne wywierają istotny wpływ na poszczególne obszary życia społecznego w tym również dla administracji publicznej. Podmioty administracji publicznej uczestniczą (w zróżnicowanych stopniach zaangażowania) w ich tworzeniu, ponadto należą najczęściej do najbardziej istotnych elementów służących ich realizacji i ewaluacji. W związku $\mathrm{z}$ tworzeniem i wdrażaniem polityk publicznych administracja publiczna jest istotnym aktorem rozwiązywania problemów społecznych. Realizacja polityk publicznych pozostaje w sferze zainteresowania polityki administracyjnej, ponie-

${ }^{26}$ J. Izdebski, ... dz. cyt., s. 167. 
waż można ją traktować, jako element składowy szerszego procesu, jakim jest tworzenie i wdrażanie szczegółowych polityk publicznych i wynikający z nich programów publicznych. Przedstawione zależności wskazują na istotne znaczenie współpracy pomiędzy badaniami naukowymi w zakresie polityk publicznych $\mathrm{z}$ prawnymi podstawami działania administracji publicznej w ramach nauk administracyjnych.

\section{Bibliografia}

J. Boć, T. Kuta, Prawo administracyjne. Zagadnienia podstawowe, Warszawa 1984.

Z. Duniewska, Zakres regulacji prawa administracyjnego materialnego - wyznaczenie pojęcia instytucji tego prawa, [w:] R. Hauser, Z. Niewiadomski, A. Wróbel (red.), System prawa administracyjnego. Tom 7. Prawo administracyjne materialne, Warszawa 2012.

H. Izdebski, M. Kulesza, Administracja publiczna. Zagadnienia ogólne, Warszawa 2000.

J. Izdebski, Koncepcja misji administracji publicznej w nauce prawa administracyjnego, Lublin 2012.

J. Izdebski, Pojęcie i zakres polityki celnej w ujęciu polityki administracyjnej, [w:] J. Łukasiewicz (red.), Polityka administracyjna, IV Międzynarodowa Konferencja Naukowa Stryków 7-9 września 2008 r., Rzeszów 2008.

J. Jagielski, Rozważania nad pojęciem i istotą prawa administracyjnego materialnego, [w:] R. Hauser, Z. Niewiadomski, A. Wróbel (red.), System prawa administracyjnego. Tom 7. Prawo administracyjne materialne, Warszawa 2012.

M. Jełowicki, Nauka administracji. Zagadnienia wybrane, Warszawa 1987.

E. Knosala, Zarys nauki administracji, Kraków 2005.

D. Kozaczka, Polityki publiczne, jako proces, Zoon Politikon, Nr 72016.

M. Kulesza, D. Sześciło, Polityka administracyjna i zarzq̨dzanie publiczne, Warszawa 2013.

Z. Leoński, Materialne prawo administracyjne, Warszawa 2009.

Z. Leoński, Nauka administracji, Warszawa 2004.

Z. Leoński we współpracy z R. Hauserem i A. Skoczylasem, Zarys prawa administracyjnego, Warszawa 2004.

I. Lipowicz, Prawne formy działania administracji publicznej-między stabilizacją a potrzebą przełomu, Ruch Prawniczy, Ekonomiczny i Socjologiczny, Rok LXXVIII - zeszyt 4 - 2016.

A. Makuch, Rola administracji publicznej wświetle wybranych nurtów i doktryn politycznych [w:] A. Gołębiowska, B. Zientarski (red.) Koncepcje i instrumenty zarządzania w administracji publicznej, Kancelaria Senatu, Warszawa 2017.

M. Małecka-Łyszczek, Wpływ wybranych prawnych form działania administracji na natężenie współpracy z podmiotami ekonomii społecznej, Ekonomia Społeczna, Nr 3 (8) 2013.

Z. Niewiadomski, Pojęcie administracji publicznej, [w:] R. Hauser, Z. Niewiadomski, A. Wróbel (red.), System prawa administracyjnego, T. 1: Instytucje prawa administracyjnego, Warszawa 2010.

Z. Niewiadomski, Istota i miejsce prawa materialnego w systemie prawa administracyjnego, [w:] Z. Niewiadomski (red.), Prawo administracyjne. Część materialna, Warszawa 2004.

J. Starościak, Prawo administracyjne, Warszawa 1977.

J. Szreniawski, Wstęp do nauki administracji, Lublin 2000.

J. Woźnicki, Nowa dyscyplina - „nauki o polityce publicznej" usytuowana w dziedzinie nauk społecznych, Nauka Nr 1/2012.

K. M. Ziemski, Indywidualny akt administracyjny jako forma prawna działania administracji, Poznań 2005.

A. Zybała, Polityki publiczne, Krajowa Szkoła Administracji Publicznej, Warszawa 2012. 
Streszczenie:

Współczesna administracja publiczna jest zaangażowana w realizację zadań, które są elementem polityk publicznych ukierunkowanych na rozwiązywanie złożonych problemów społecznych. Sposób tworzenia i realizacji poszczególnych polityk publicznych stawia przed podmiotami administracji publicznej istotne wyzwania. Złożoność powierzonych podmiotom administracji publicznej funkcji w realizacji polityk publicznych powoduje konieczność ich prawidłowego ujęcia w podstawach prawnych funkcjonowania administracji publicznej, w szczególności prawnych formach działania administracji publicznej oraz sposobu ujęcia kompetencji organów administracji publicznej uregulowanych materialnym prawem administracyjnym. Wskazane zależności warunkują konieczność współpracy pomiędzy dyscyplinami naukowymi mającymi za przedmiot w szerokim ujęciu realizację zadań państwa oraz funkcjonowanie administracji publicznej.

Słowa kluczowe: Administracja publiczna, Prawo administracyjne, Polityki publiczne.

\section{Implementation of the public politics by the public administration}

\section{Summary:}

The contemporary public administration is engaged in implementation of the tasks that are the part of the public politics aiming to solve the complex social problems. The manner of creating and achieving each of the public politics is a challenge for the public administration entities. The complexity of the functions entrusted to the public administration entities in the implementation of the public politics causes the necessity of the correct recognition of those politics in the legal basis of the functioning of the public administration, in particular in the legal forms of acting by the public administration and the way of recognizing the competences of the public administration bodies regulated in the substantive administrative law. The indicated dependences cause a necessity to cooperate between the scientific disciplines that implement in the broad scope the state's tasks and the functioning of the public administration.

Keywords: public administration, administrative law, public politics. 